\title{
Disney: crime in fairy tales*
}

\author{
Monica Calderaro, ${ }^{1}$ Marta Senesi ${ }^{2}$ \\ ${ }^{1}$ Criminologist, graphologist, headmaster and professor of the Graphology course of Sapienza University of Rome. \\ Professor of Psychographology and Crime in social media of the Master of Criminology in the University of International \\ studies of Rome (UNINT). Researcher of the International Institute of Criminological and Psychopathological forensic \\ science (IISCPF); ${ }^{2}$ Master in Criminologia e Scienze Strategiche Sapienza Università di Roma; Member of the \\ International institute of Criminological and Psychopathological forensic science (IISCPF). Tutor of the Master of \\ Criminology, University of international studies of Rome (UNINT), Italy
}

*Translated from Italian by Giulia Maestoso

\begin{abstract}
The screen is colored by a celestial sky and begins to outline a castle under whose white gold stands the "Walt Disney Pictures", a semi-crown crown all and the doors of the fantasy are ready to open to the spectators. This is the classic presentation of a Disney Movie that at least once in a lifetime will happen to each of us to attend and accompany the childhood of millions of children. But what is waiting behind that castle? Charming spells and sparks of magic? Absolutely. Princesses to save and charming princes to dream? Absolutely yes. Speaking animals and an Never Land? All this and much more. But if we looked at that castle from a different perspective, and if we shifted our attention from the precious robe of the protagonist, to what deeply motivates her choices and the dynamics surrounding her, we could notice dark shadows, concealed by glittering jewels and unnatural sunsets, so brilliant to blind. The work will focus on those heaviest nuances, analyzing and deepening scenes and themes of Disney Movies where it will be possible to find criminological and psychopathological aspects, thus trying to connect two worlds so distant that for a moment they will intersect as well as in a palette of a painter you can mix white and black.
\end{abstract}

\section{RIASSUNTO}

Lo schermo si colora di un celeste cielo, e comincia a delinearsi un castello sotto la cui bianca aurea si staglia la sigla "Walt Disney Pictures", un semiarco corona il tutto e le porte della fantasia sono pronte a schiudersi per gli spettatori. Questa è la classica presentazione di un Film Disney a cui almeno una volta nella vita sarà capitato a ciascuno di noi di assistere, e che accompagna l'infanzia di milioni di bambini. Ma cosa ci aspetta dietro quel castello? Affascinanti incantesimi e scintille di magia? Senz'altro. Principesse da salvare e principi azzurri da sognare? Assolutamente sì. Animali parlanti e un'isola che non c'è? Tutto questo e molto di più. Se guardassimo, però, quel castello da una prospettiva diversa, e se spostassimo l'attenzione dal vestito prezioso della protagonista, a ciò che motiva in profondità le sue scelte e alle dinamiche che la circondano, potremmo notare delle sfumature oscure, celate da sfavillanti gioielli ed innaturali tramonti, tanto brillanti da accecarci. È proprio su quelle sfumature più tetre che si concentrerà il lavoro, analizzando e approfondendo scene e temi dei Film Disney in cui sarà possibile riscontrare aspetti criminologici e psicopatologici, cercando così di connettere due mondi tanto distanti che per un attimo si intersecheranno, cosi come in una tavolozza di un pittore è possibile mescolare il bianco e il nero.

\section{RESUMEN}

La pantalla es de color azul claro del cielo, y comienza a tomar forma un castillo bajo cuyo blanco de oro se coloca la abreviatura "de Walt Disney Pictures", un semi-arco rodea el todo y las puertas de la imaginación están listos para salir del cascarón para los espectadores. Esta es la presentación clásica de una Película de Disney que al menos una vez en la vida nos ha sucedido a cada uno de nosotros para asistir, y que acompaña a millones de niños. Pero, ¿qué está esperando detrás de ese castillo? Encantadores hechizos y chispas de magia? Absolutamente. ¿Princesas para salvar y príncipes azules para soñar? Absolutamente sí ¿Animales que hablan y una isla que no está allí? Todo esto y mucho más. Si observamos, sin embargo, que el castillo desde una perspectiva diferente, y si a mitad de camino a través de la atención por parte del precioso vestido el personaje principal, lo que motiva profundamente en sus elecciones y la dinámica que lo rodean, se puede notar las sombras oscuras, ocultas por las joyas espumoso y puestas de sol antinaturales, tan brillantes para cegar. Es precisamente en los tonos más sombríos que se centrarán los trabajos, analizando y profundizando escenas y películas temas de Disney, donde se pueden encontrar aspectos criminológicos y psicopatológicas, tratando así de conectar dos mundos tan lejos que un momento se cruzará, así como en una paleta de un pintor puede mezclar blanco y negro.

\section{Beauty and the Beast: love story or illness?}

It is one of the best-known and most romantic love stories ever to see the beautiful and simple country girl, "Belle," and a prince imprisoned in the body of a scary and horrible beast. The beast, ini- tially infuriated by violent collision attacks, and pervaded by an irascible and impulsive instinct, embodies appearances and features that hardly match the ideal boy's dream prototype. By the hand, however, that the Beast can dominate its own impetus, Belle, with an extraordinary sensitivity of mind, sees in him unexpected sweetness, and day after day learns to know a different beauty, the beauty 
of the heart. At the beginning of the film, Belle's father, Maurice, falls into the Beast's prisoner after having come across mistakenly in his castle. Belle, in order to save his father's life, agrees to be captured by the Beast in his place, without hesitation in his clutches. So, if we wanted to give a criminological reading of the plot, we would notice instantly that Belle falls in love with the Beast during a period of kidnapping, and that this dynamic coincides perfectly with a phenomenon called "Stockholm Syndrome".

Stockholm's syndrome is one of the greatest paradoxes of mental health that intrigues, fascinates and at the same time frustrates both psychiatrists and psychologists and law enforcement. This is a phenomenon that experts find difficult to interpret and define, a phenomenon that encourages the emergence of an emotional bond between kidnapper and hostage. The term was coined as a result of the original episode, in which a similar situation occurred; On an August 1973 morning, four Stockholm city bank employees were hunted by two robberies for a period of 131 hours. Despite the calvary they had to face, as a result of the incident, the victims said they did not feel resentful to the kidnappers, but rather feared the police more. What aroused even more clamor was the love affair that one of the victims set up with a seizure, and the fact that during the trial some hostages testified in favor of the kidnappers and clemency was also required for them.

Most professionals who deal with the phenomenon from a psychoanalytic viewpoint believe that it may be the result of the activation of some defense mechanisms, including identification with the aggressor and regression.

- The concept of identification with the aggressor: is a form of identification made by the ego in order to avoid anger and potential punishment by the enemy, and thus to protect themselves from authoritarian figures that cause anxiety. Such mechanism would therefore lead the victim to normalize the sufferings suffered, making them more easily bearable, from the moment when, through a distortion of reality, the victim assumes and shares the prospect of the assailant.

- Through regression, the victim invents the preservation instinct; as the newborn develops positive feelings towards adults, from whom it is dependent on the protection and satisfaction of primary needs, hence, in a kidnapping scenario, hostage takes on the role of the infant and the abuser of the adult who it takes care of it, establishing a symbiotic relationship.

Of course, Stockholm's syndrome does not foresee that emotional feelings are born exclusively in one way, from the victim to the kidnapper, but in most cases even the kidnappers remain involved. Specifically, when the victim affirms his identity, which is recognized as such, and does not make him/her anonymous in the eyes of the kidnapper, he/her will find, therefore, less and less natural to hurt the victim. It seems that the author of the seizure may be to some extent influenced by the unconscious need to be loved, and that it is driven by a sense of gratitude for the collaboration and consideration received, just as it happens to the Beast, who revisits in Belle an occasion of redemption after years of solitude, remorse and appeals.

Recently there have been some assumptions necessary for the syndrome to manifest:

- The victim must be detained as a hostage for a significant period; even if the time period is not established with certainty, it seems that three days are often enough to establish solid links between kidnappers and kidnappers. In fact, this time span is used by the victim to overcome the initial shock state, to become aware of his/her condition, trying to mitigate the effects. Just as it is represented by the Disney movie where exactly the third day of imprisonment, Belle begins to look at the Beast with different eyes and to find out the most positive aspects.

- Hostages and seizures are to maintain a continuous interper- sonal relationship; the victims are therefore not forced into a state of marginalization, but rather share isolation from the rest of the world with the kidnappers that fosters their sense of union. Even the Beast, like Belle, is marginalized by the human world, rejecting him as a social rejection.

- The kidnappers must treat the hostages kindly, or at least not abuse them physically and not threaten them verbally. The absence of severe traumas increases the likelihood that the syndrome will develop, while milder negative experiences, such as being humiliated or deprived of something, tend to be normalized by the victims and deemed necessary for the kidnappers to succeed keep the order and control of the situation, or they can be interpreted as a lawful punishment for their own mistake.

- The shared hostile perception of law enforcement: not only seizures, but also seized, consider police intervention as a threat. Victims fear that attempts by the armed forces to bring about the surrender of the offender, and the possibility of an incursion, could undermine their security, as well as the fact that the trust in police protection has failed in the hostages since the seizure took place. It looks like a photograph of what happens at the end of Disney's film, when the country's uprising led by the superficial Gaston rages in the Beast Castle to destroy it, and Belle does everything to prevent and save his life.

\section{Snow White and the kiss of Necrophile Prince}

Princess Snow White, once killed by the famous poisoned apple, retains untouched beauty, so that the dwarves do not find the courage to bury her. Instead, they decide to put her in a gold and crystal urn. At this point of the fairy tale, what is most disturbing is the bizarre conduct of the Prince, who as soon as he learns of the girl lying in the woods, races to her and kisses her. And if we did not know the end, if we did not know that it is precisely because of that kiss that Snow White awakens, all this will surely suspend the spectator. A macabre dose would sweep away, instantly, the scent of romance.

Are not we, therefore, facing a carnal act on a lifeless body?

Necrophilia is one of the most abnormal and insane practices that belong to the sphere of degenerate sexuality. It is a paraphilia in which the subject of sexual excitement is represented by a corpse, and is a very rare manifestation that often appears in conjunction with other perversions such as cannibalism, necrophagy or vampirism. Here are some types of the disease in question, from a categorization system proposed by Anil Aggrawal (2008).

1. "Role Players": They present a form of moderate atypicality, seeking sexual stimulation with living subjects pretending to be deceased. In some closed houses in Paris, prostitutes simulate being inanimate bodies, made to be very pale, covered in a white sheet and stretched out over a coffin.

2. "Romantic Necrophils": In this type are those who are facing an untreated mourning, and consequently reject a physical detachment from their loved one. They mummize the bodies of their loved ones or just a few parts to pursue a sexual relationship with their partner, just as they did before their death. Our Prince Disney, may be just a romantic necrophile, who does not give up in front of the deceased of his beloved.

3. "Necrophil Mutilators": Their erotic fulfillment comes from mutilating a deceased body and contemporary masturbating action; During this perpetration, the individual can also eat shreds of the deceased.

4. "Necrophil Homicides": As suggested by the very name of their classification, they are considered the most fearsome and worrying. The sexual thrust they perceive as a secretion is so intense 
and persistent that they lead them to kill, precisely in view of the resulting erotic relationship they will consume with it.

Mortuary assistants are, uncommonly, involved in necrophilic practices; according to several authors, this could be due to an excessive feeling of solitude and marginalization, or just from the necrophilic nature of the individual, which influenced him in choosing his or her job, so that there is free access and extensive availability of dead bodies. In terms of psychological analysis, regarding so reprehensible and abusive acts, most professionals would bring them back to trauma and child sexual violence and, on the other, to the deviated logic that the deceased has no chance of denying or diverting the assailant or obstructing him, or even witnessing the violence he has suffered.

\section{The Sword in the Stone: "loves me or loves me not" and the erotomaniac delirium}

The famous scene of The Sword in the Stone has already passed through history, in which Merlin and Arthur Pendragon are faced with a complication that even magic can not solve when they are transformed into squirrels and face a real pursuit between trees, branches and bushes of the forest, trying in vain to escape the squirrels who, in love and belief that their infatuation is paid, seek their attentions. It is the triumph of the philosophy "loves me or loves me not", a cheerful frame that arouses tenderness towards the admirers, so affectionate and constantly rejected. As always, however, it is appropriate to sharpen the gaze, to realize that this frame has little cheerful, while it definitely has a name: erotic delirium.

It is a morbid passional syndrome in which prevails the centrality of an elaborate and systematic amusing illusion. Specifically, the erotomanic patient (referred to in feminine terms as it is a typically feminine affair) is absolutely convinced that she is loved by another person, who presumably would manifest devotion through hidden and clandestine spells. Generally, women suffer from a modest cultural background, while the love object is personified by older men, respected and belonging to a high social and financial layer (such as celebrities, doctors, executives), married, or unreachable for other reasons. Although the patient firmly argues that the object was the first to declare his passion, which can describe the evidence in detail (unequivocal exchanges of views, messages sent through newspapers or passers-by, telepathic communications) they only had some random contact, or even never met. The patient can repudiate the imaginary adoration of the object, but much more often she falls in love obsessively. Despite the waste of any form of romantic participation by the subject, the illusion persists, usually for years, during which the woman remains caste, sometimes requires hospital admission or legal action to prevent harassment. In fact, disinterest is justified by contorted and machinable conjectures, which are often confabulates, and act adequately as a defense for the patient, which will intensify any extreme and explicit opposition by the subject. Returning this first overall picture to Disney's masterpiece, it is clear that squirrels, that feel inferior to their beloved (as human beings), and entirely certain of the reciprocity of sentiment, personify the delirium in full swing. Two real cases of gravity will be discussed below, the first outlined by De Clérambault himself in 1921, and the second, closer to our day, drawn from an American Psychiatric Journal.

\section{For King's Love}

A 53-year-old French woman, had developed over time the unconditional belief that George V, King of England, was in love with her. She felt that British tourists who were in France were messengers sent by the king to announce her love for her. Before the illusion just mentioned, the woman had also believed that an American general and King Edward VII were devoted to her at a passionate level. During his many trips to England, he waited patiently outside the gates of Buckingham Palace. Once, seeing a tent move around a window, she interpreted it as a sign of the sovereign. He claimed that the news of their sweet secret was spreading to London, and the king provided for the vanishing of luggage containing coins and portraits that depicted him. Despite these difficulties, which she should have discouraged, she continued to support the existence of a special relationship between her and George V: "The King may hate me, but he will never forget. He could never be indifferent to me, nor could I be with him".

\section{Doctor McDreamy}

It is the story of a twenty-one-year-old patient who has an evolved illusory system; when she began talking about her boyfriend, it seemed that they were involved in a loving relationship, although they had never even had an appointment and had only been seen once during a university lesson. She kept repeating that she was aware of the tremendous love he felt for him, and that she felt attracted to him precisely because of that feeling. She understood how much the boy felt blank without her, and that's why he is looking for her, despite the enemies who constantly try to divide them. The antagonistic people the young woman refers to include her family, her classmates, her neighbors, and many others who are plotting to keep them separate. According to her version, he even sent her love messages to show his love through specific car plates, purple color and other clues from the surrounding environment. Also, she is aware of how meaningful she is to the boy's life and vice versa, though they are not together yet; she would never give up to another man besides him, otherwise she would be unfaithful, and that is why she will wait for him eternally. The patient says that the world is also aware of the relationship, including the President of the United States and other prominent people. After a few years, the condition of the young woman did not improve; she thought her boyfriend went to visit her at night, that they were married and had many children who were then taken away from her by her family and psychiatrists, without her consent. After receiving a pharmacological treatment, her disease has decreased for a few weeks, but shortly afterwards it has reappeared".

\section{The Mad Hatter Syndrome and mercury poisoning}

It is one of the most exhilarating scenes of "Alice in Wonderland": everything is ready, the table is set, with cups and cups of all kinds and color, the background music resounds to celebrate a "Very Marry Unbirthday" and to crown the banquet there are sweets, biscuits, but especially tea, so much tea. Here comes the most famous and popular character of the Disney masterpiece: The Mad Hatter. He dressed bizarre, capable of pouring tea by making it go from the sleeve of his jacket, and lover of no sense guesses, like the famous "Why are sunsets puppets to lift?". It is quite evident to what type of syndrome the author of the story wanted to refer to: The Mad Hatter Syndrome.

It is also called mercury poisoning syndrome, and compromises both physical, psychiatric and neurological functioning of the subject. The term was coined in the early nineteenth century, and refers to the period when mercury was introduced in the British manufacturing industry of felt hats, to speed up its production process. The chapels inhaled such mercury, a toxic substance that can easily cross the muscle tissue, even the heart, and the cerebral barrier, affecting the central nervous system and even leading to death. The damage caused to 
those who carried out this type of work also had social effects, so that the chapels were labeled as unstable and dangerous people.

The most common symptomatology for those with a minimum but prolonged poisoning is as follows:

\section{Physical Symptoms}

- Skin rashes and easy to blush: Alice's chapel, in fact, has reddish red flashes in her face.

- Tremors

- Loss of coordination in motion

- Weakness

- Barcollant running

- Color of iris of a green light

- Hair loss: in the Mad Hatter you notice an accentuated balding

Psychic Symptoms

- Reduced mental capacity

- Depression

- Anxiety

- Shameful

- Loss of self-esteem

- Irritability: In fact, the Disney character often lacks calm

- Distrust

- Memory Loss: Alice is forced to repeat her words to the Mad Hatter.

- Mental Confusion: The Mad Hatter can not speak lucidly and pronounce meaningful speeches.

- Loss of control over strangers

- Psychic discomfort and sudden change of mood: initially the Mad Hatter does not welcome Alice with goodwill, rebuking her that she has not been invited for tea; a few moments later, he changes his mind and enthusiastically hosts her to their private home.

This partly reflects behavioral bipolarity and schizoid personality, on one hand dominating the rejection of the other by the fear of abandonment, and on the other hand, the quest for affection and contact with the neighbor.

Generally, those who have suffered heavy intoxication may find themselves in a semi-rigid posture, usually crying and making involuntary and primitive reflex movements.

\section{Neurological Deficit}

- Compromise of language and hearing

- Deficit in word processing: This is probably Wernicke's
Aphasia, which consists of a fluent, but controversial speech with disjointed speech.

- Trend to bump

\section{Conclusions}

Despite any fairy-tale and surreal expectation, this work has led to dramatic and very little romantic: princes and princesses far from perfection; characters that, though pleasing to the screen, enclose the most unthinking and disturbing pathologies; without neglecting recurring dynamics, such as hypnotic ones, which, though reduced to a touch of magic, are, in fact, more complex and obscure entities. The intent is not to worship such masterpieces, which, by aesthetic harmony and ethical ingredients, share the same value as a work of art or poetry. Indeed, this explosive blend of good and bad is what makes them even more fascinating and worthy of being watched at least once in life, not just by children, but also by adults.

\section{References}

AGGRAWAL A. (2009), A new classification of necrophilia, Journal of Forensic and Legal Medicine, 16, pp. 316-320.

FAVARO A., DEGORTES D., COLOMBO G. (2000), The effects of trauma among kidnap victims in Sardinia, «Psychological Medicine», 30(5), pp. 975-980.

GABBARD G.O. (1995), Psichiatria Psicodinamica, Milano, Raffaello Cortina Editore.

GRAHAM D.L., RAWLINGS E.I. (1995), A scale for identifying Stockolm Syndrome reactions in young dating women: factor structure, reliability and validity, "Violence Victims», 10(3), pp. 3-22.

JORDAN H.W., LOCKERT E.W. (2006), Erotomania revisited: thirtyfour years later, «Journal of The National Medical Association», 98(5), pp. 787-793.

LICHTENBERG H. (1996), Mercury vapour in the oral cavity in relation to number of amalgam surfaces, «Journal of Orthomolecular Medicine», 11(2), pp. 87-93.

SEGAL J.H. (1989), Erotomania revisited, «Am J Psychiatry», 146(10), p. 1261.
Correspondence: Monica Calderaro.

E-mail: monica.calderaro@uniroma1.it

Key words: Crime; tales; movies; cartoons; psychopathology. Parole chiave: Crimine; favole; film; cartoni animati; psicopatologia. Palabras clave: Delito; fábulas; película; dibujos animados; psicopatología.

Received for publication: 5 October 2016.

Revision received: 12 June 2017.

Accepted for publication: 17 July 2017.

(C) Copyright M. Calderaro and M. Senesi, 2017

Licensee PAGEPress, Italy

Rivista di Psicopatologia Forense, Medicina Legale, Criminologia 2017; $22: 27-30$ 